removed. The stimulation of flowering, following removal of young leaves, may result from the release of an inhibitory factor originating from the young developing leaves (Leopold and Lam, 1960) and/or a greater supply of assimilates made available as a consequence of the removal of these leaves (Aung and Kelly, 1966). Our results suggest that the amount of axillary leaves present on the plant before fruiting exhibits the greatest influence on early fruiting and that early fruiting was inversely proportional to the relative amount of axillary leaves. Plants from the main leaf removal treatment and control treatment had different main and total leaf areas, but had similar axillary leaf areas and responded similarly in number of early fruit produced. Early fruiting was increased by removing the axillary leaves. The delay in fruiting following decapitation has been reported by others (Brown et al., 1971) and is probably a consequence of increased axillary shoot growth.

Cultural practices for tomato that remove leaves or apical buds to influence yields also affect the leaf development and distribution of main and axillary leaves. Abetter understanding of the consequences of leaf removal and decapitation on resulting leaf development should assist in the development of improved practices and/or cultivars for tomato.

\section{Literature Cited}

Adegoroye, A.S. and P. A. Jolliffe. 1983. Initiation and control of sunscald injury of tomato fruit. J. Amer. Soc. Hort. Sci. 108:23-28.

Aung, L.H. 1976. Influences of certain plant factora on the growth and fruiting of the lower axillary shoot of Lycopersicon esculentum Mill. Ann. Bet. 40:723-729.

Aung, L.H. and J.M. Byrne. 1978. Hormones and young leaves control development of cotyledonary buds in tomato seedlings. Plant Physiol. 62:276-279.

Aung, L.H. and W. C. Kelly. 1966. Influence of defoliation on vegetative, floral and fruit development in tomatoes (Lycopersiccm esculentum Mill.). Proc. Amer. Soc. Hort. Sci. 89:563570.

Brown, R. T., T.P. Hernandez, and A. Adams. 1971. Study shows effects of pruning on tomato production. Louisiana Agr. 14:14-15.

canner, S.G. and W.M. Walker. 1982. Baby bear's dilemma: A statistical tale. Agron. J. 74:122124.

Catalano, M. and T.A. Hill. 1969. Interaction between gibberellic acid and kinetin in overcoming apical dominance, natural and induced by IAA, in tomato (Lycopersicon esculentum Mill. cultivar Potentate). Nature (London) 222:985986.

Decoteau, D. R., M.J. Kasperbauer, D.D. Daniels, and P.G. Hunt. 1988. Plastic mulch color effects on reflected light and tomato plant growth. Scientia Hort. 34:169-175.
Huasey, G. 1963a. Growth and development in the young tomato. I. The effect of temperature and light intensity on growth of the shoot apex and leaf primordia. J. Expt. Bet. 14:316-325.

Hussey, G. 1963b. Growth and development in the young tomato. II. The effect of defoliation on the development of the shoot apex. J. Expt. Bot. 14:326-333.

Leopold, A.C. and S. L. Lam. 1960. A leaf factor influencing tomato earliness. Proc. Amer. Soc. Hort. Sci. 76:543-547.

Paul, E.M.M. 1984a. The response to temperature of leaf area in tomato genotypes. I. Cell size and number in relation to the area of a leaf. Euphytica 33:347-354.

Paul, E.M.M. 1984b. The response to temperature of leaf area in tomato genotypes. 11. The rate of leaf production. Euphytica 33:355-362.

Rubenstein, B. and M.A. Nagao. 1976. Lateral bud outgrowth and its control by the apex. Bet. Rev. 42:83-109.

Tucker, D.J. 1975. Far-red light as a suppressor of side shoot growth in the tomato. Plant Sci. Lett. 5:127-130.

Tucker, D.J. 1977. The effects of far-red lighten lateral bud outgrowth in decapitated tomato plants and the associated changes in the levels of auxin and abscisic acid. Plant Sci. Lett. 8:339-344.

Watts, V.W. 1937. Growth and fruiting responses to pruning and defloration of tomato plants. Univ. of Arkansas, Expt. Sta. Bul. 347.

Wolk, J. O., D.W. Kretchrnan, and D.G. Ortega. 1983. Response of tomato to defoliation. J. Amer. Soc. Hort. Sci. 108:536-540.

\title{
Regeneration of Lachenalia Species from Leaf Explants
}

\author{
Josephina G. Niederwieser and Bela M. Vcelar \\ Vegetable and Ornamental Plant Research Institute, Private Bag X293, \\ Pretoria, 0001 Republic of South Africa
}

Additional index words. bulb, Lachenalia, tissue culture, physiological stage, explant orientation, explant size, and wounding

\begin{abstract}
The physiological stage of donor plants determined to a great extent the morphogenic potential of Lachersalia (Jacq.) hybrid leaves, but the optimal stage for various cultivars was different. Contact of the bud-forming adaxial epidermal cells with the medium did not significantly stimulate in vitro bud formation on Lachenalia leaf explants, but resulted in the formation of callus from the buds of certain hybrids. Wounding on either the adaxial or the abaxial side of leaves had a stimulating effect on certain hybrids, but others did not respond significantly. A reduction in the length of explants from 10 to $3.3 \mathrm{~mm}$ resulted in an increase in the total number of buds formed by a specific amount of explant tissue (width of explant $=15 \mathrm{~mm}$ ).
\end{abstract}

Lachenalia, a genus of the Hyacinthaceae, is a seasonal bulb endemic to southern Africa and is currently being developed for use as a pot plant. The mass propagation of Lach-

Received for publication 24 Jan. 1989. We thank M. Smith of the Directorate Biometrical and Datametrical Services of the Dept. of Agriculture and Water Supply for statistical analysis of data. The cost of publishing this paper was defrayed in part by the payment of page charges. Under postal regulations, this paper therefore must be hereby marked advertisement solely to indicate this fact. enalia hybrids by means of tissue culture was first reported by Nel (1983). The first step in this process was the production of adventitious buds from adaxial epidermal cells of leaf tissue (Van Rensburg and Van Staden, 1988) to obtain first-generation shoots. These shoots could be subdivided repeatedly until the required number of shoots was obtained (Nel, 1983). The effects of the physiological stage of the donor plant and the orientation, wounding, and size of the explant on the initiation of first-generation buds from Lachenalia leaf tissue are discussed here.
Lachenalia cultivars and hybrids were used. Bulbs were planted in autumn in equal parts of loam, sand, and compost. Plants were cultivated in a commercial greenhouse with average minimum of $5 \mathrm{C}$ and average maximum of 21C. The daylength followed the natural seasonal pattern in the Southern Hemisphere. Plants were watered twice weekly and received no additional nutrients. The culture medium consisted of the inorganic salts of Murashige and Skoog (1962), $5 \%$ sucrose, $1 \mathrm{mg} \cdot$ liter $^{-1}$ each of benzylamino purine (BA) and naphthaleneacetic acid (NAA), $100 \mathrm{mg}$ inositol/liter, and $0.7 \%$ agar. The $\mathrm{pH}$ was adjusted to 5.7 before autoclaving. Leaves were surface-sterilized by soaking them in $1 \% \mathrm{NaOCl}$ for 30 rein, followed by rinsing in sterile water. Cultures were kept at $23 \mathrm{C}$ and a photoperiod of $12 \mathrm{hr}$. Except where stated otherwise, donor plants in full bloom were used. Surface-sterilized leaves were cut into explant squares and these were cultured horizontally, with the abaxial surface on the. medium. The size of explants was $15 \times 10 \mathrm{~mm}$, except where stated otherwise. Each experiment was done with five to eight leaves of each hybrid and with four to six replicates per leaf, depending on the size of the leaf. Buds formed directly from leaf tissue, and, 4 weeks after growth had started, the number of buds formed per explant was determined. Except in the experiment on the physiological stage of the donor plant, where tissue was cultured in $19 \times$ 125 -mm test tubes containing $10 \mathrm{ml}$ of medium, explants were cultured in compart- 


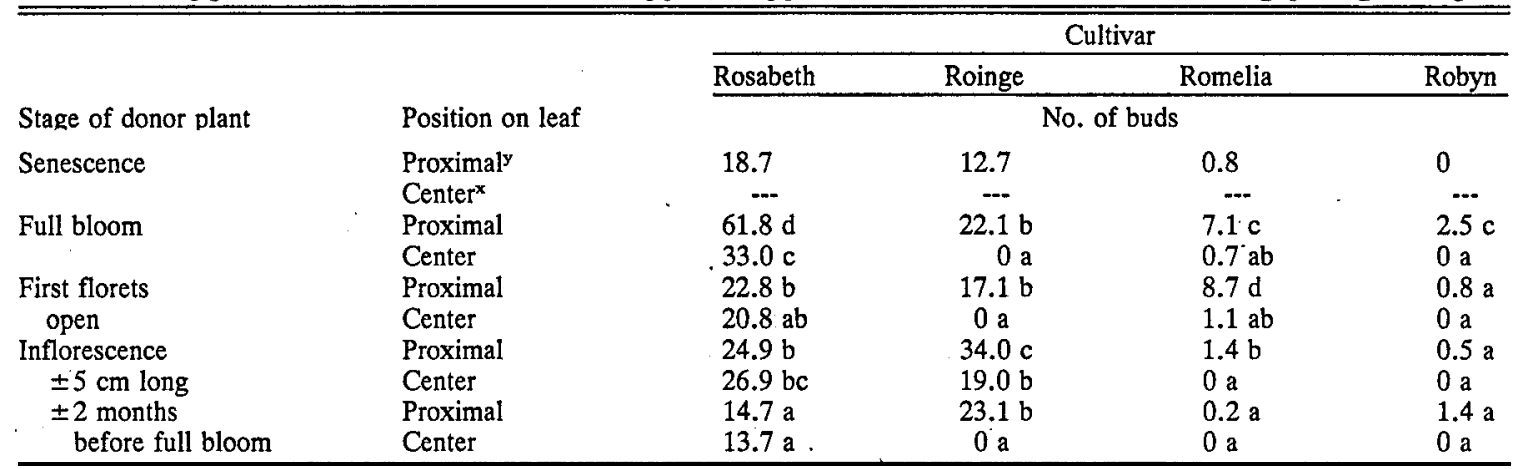

The numbers given are calculations based on a regression model. Values followed by the same letter do not differ significantly $(P<$ $0.05)$, and the significance of differences between values was determined separately for each cultivar.

${ }^{y}$ Tissue from the center of the leaf was not cultured, as it was wilted or chlorotic.

${ }^{x}$ These values could not be included in the analysis to determine the standard errors for senescent tissue, as no data on the potency of the tissue from the center of the leaf were available.
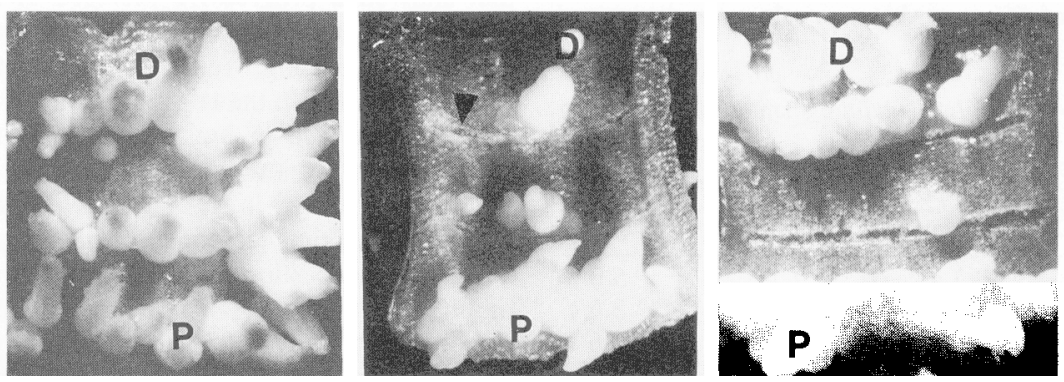

Fig. 1. Bud formation on wounded leaf explants, of the Lachenalia hybrid 78/93/112. (left) Bud formation on the adaxial side of an explant that was wounded on the abaxial side. Bud formation on an explant wounded on the adaxial side: (middle) explant dissected from the distal half of the donor leaf and (right) explant dissected from the proximal end of the leaf.

mentalized petri dishes, with $2.5 \mathrm{ml}$ of medium in each compartment. As data were unbalanced, a regression analysis was done, using the Genstat V program [Lawes Agricultural Trust (Rothamsted Experimental Station), 1984]. The 5\% level was taken as criterion for significance.

Genotype and position of explant. To test for the effect of genotype, each experiment included at least four hybrids. The position of each explant on the donor leaf was noted to determine whether that would affect bud formation. Each leaf was divided transversely into a proximal, center, and third section, with the proximal tissue the youngest and the distal tissue the oldest.

Physiological stage of donor plants. Four cultivars ('Robyn', 'Rodeas', 'Roinge', and 'Rosabeth') were used. Leaf tissue was cultured six times during the seasonal growth cycle starting from $\approx 2$ months before full bloom to the stage when plants were approaching dormancy after flowering. Explants were cultured singly in test tubes. Results were obtained from at least 31 explants per cultivar, dissected from seven to eight leaves for each stage.

Explant-orientation. The aim of this experiment was to determine whether contact of the bud-forming adaxial epidermis with the medium would stimulate bud formation. Explants of six genotypes were cultured horizontally, with either the adaxial or the abaxial epidermis on the medium.

Wounding. The response of intact explants was compared with that of wounded ex- plant;. Wounding was by two transverse cuts, $3 \mathrm{~mm}$ apart, in the center of the explant on either the adaxial or the abaxial side. The depth of the cuts was estimated so that the vascular bundles were not damaged. Seven hybrids were used in this experiment.

Explant size. Explants of three sizes were cultured. The control treatment consisted of one explant, $15 \mathrm{~mm}$ wide and $10 \mathrm{~mm}$ long. (The length was the longitudinal and the width the transverse side.) The first size treatment consisted of two explants, each $15 \mathrm{~mm}$ wide and $5 \mathrm{~mm}$ long, and the second size treatment of three explants, each $15 \mathrm{~mm}$ wide and $\approx 3.3 \mathrm{~mm}$ long. Thus, the total size of leaf surface in each treatment was the same, and the explants of each treatment were cultured together in one petri dish compartment. The experiment was repeated on five hybrids.

Genotype and explant position on the leaf Genotype had a statistically significant effect on the average number of buds formed per explant. In general, the morphogenic potential of the tissue was highest near the leaf base (young tissue) and decreased toward the leaf tip (old tissue). Unless a significant interaction between the effect of the treatment and the position of the explants on donor leaves was found, only the results obtained from the proximal $3 \mathrm{~cm}$ of leaves are given.

Physiolo "cal stage of donor plants. The regeneration potential of leaf tissue of 'Rosabeth', 'Roinge', and 'Romelia' was apparently affected by the physiological stage of donor plants (Table 1). The optimal stage for
'Rosabeth' leaf tissue was clearly at full bloom. Bud production by 'Roinge' tissue was optimal at the stage when inflorescences were $\approx 5 \mathrm{~cm}$ long; the only stage when tissue from the center of the leaf produced buds. The regeneration potential of 'Romelia' leaf tissue was poor before flowering, but increased toward the stage when the first florets were open. From the results obtained with 'Robyn', no clear trend was observed. However, at full bloom, the highest number of buds per explant was recorded. Only proximal tissue formed buds at all stages. Tissue of senescent leaves of 'Rosabeth', 'Roinge', and 'Romelia' formed buds, and, in the case of 'Rosabeth' and 'Romelia', the number of buds per explant was higher than the number 2 months before flowering.

Explant orientation. Buds were formed on the adaxial surface of explants, regardless of the orientation of explants. Occasionally, buds formed on the abaxial surface of explants of certain hybrids. In the case of two hybrids, $76 / 11 / 315$ and $78 / 47 / 75$, the number of buds formed per explant could not be counted accurately when explants were cultured with the adaxial side on the medium, because the buds grew abnormally to form hard, yellow, callus-like tissue (Table 2). Similar explants of the other hybrids formed marginally more buds than explants cultured with the abaxial surface on the medium. The differences, however, were not statistically significant. Although the buds did not form the same callus-like tissue as the buds of 76/11/315 and $78 / 47 / 75$, the shoots formed from them appeared thickened or abnormal. Therefore, the best results were obtained when explants were cultured with the abaxial side on the medium.

Wounding. In three of the seven hybrids used, 73/5 1/21, 76/16/76, and 76/11/76, wounding did not significantly stimulate bud formation, although a marginal increase was observed (Table 3 ). In the other four hybrids, wounding promoted bud formation, and wounding on the abaxial surface promoted bud formation more than wounding on the adaxial surface. Buds, on the adaxial side (Fig. 1), and callus, formed as a result of a wound cut, were invariably found on the distal side of the cut. 
Table 2. Average number of buds formed per leaf explant of six Lachenalia hybrids cultured with either the abaxial or the adaxial side on the medium.'

\begin{tabular}{lcccccc}
\hline \hline \multirow{2}{*}{$\begin{array}{c}\text { Side on } \\
\text { medium }\end{array}$} & $76 / 11 / 315$ & $78 / 47 / 75$ & $80 / 27 / 13$ & $76 / 11 / 78$ & $78 / 94 / 12$ & $73 / 41 / 12$ \\
\cline { 2 - 7 } & 23.8 & 12.2 & $12.8 \mathrm{a}$ & $4.8 \mathrm{a}$ & $13.0 \mathrm{a}$ & $20.4 \mathrm{a}$ \\
Abaxial & $\approx 6+$ callus & $\approx 8+$ callus & $15.9 \mathrm{a}$ & $6.7 \mathrm{a}$ & $15.9 \mathrm{a}$ & $24.0 \mathrm{a}$ \\
\hline
\end{tabular}

${ }^{2}$ The numbers given are calculations based on a regression model. Values followed by the same letter do not differ significantly $(P<0.05)$, and the significance of differences between values was determined separately for each hybrid.

Table 3. Average number of buds formed per explant on Lachenalia explants wounded on either the adaxial or abaxial side

\begin{tabular}{lcllcccc}
\hline \hline & \multicolumn{7}{c}{ Genotype } \\
\cline { 2 - 8 } Wounding & $78 / 93 / 112$ & $73 / 41 / 1$ & $75 / 18 / 41$ & $78 / 2419$ & 73151121 & $76 / 16 / 76$ & $76 / 11 / 76$ \\
\hline None & $17.7 \mathrm{a}$ & $11.6 \mathrm{a}$ & $21.1 \mathrm{a}$ & $14.8 \mathrm{a}$ & $17.5 \mathrm{a}$ & $14.5 \mathrm{a}$ & $12.5 \mathrm{a}$ \\
Adaxial side & $20.1 \mathrm{~b}$ & $17.7 \mathrm{ab}$ & $27.8 \mathrm{ab}$ & $30.3 \mathrm{~b}$ & $23.7 \mathrm{a}$ & $16.4 \mathrm{a}$ & $15.2 \mathrm{a}$ \\
Abaxial side & $28.8 \mathrm{C}$ & $20.5 \mathrm{~b}$ & $34.2 \mathrm{~b}$ & $31.8 \mathrm{~b}$ & $23.2 \mathrm{a}$ & $14.9 \mathrm{a}$ & $16.8 \mathrm{a}$ \\
\hline
\end{tabular}

${ }^{2}$ The numbers given are calculations based on a regression model. Values followed by the same "letter do not differ significantly $(P<0.05)$, and the significance of differences between values was determined separately for each hybrid.

Table 4. Average number of buds produced by different sizes of Lachenalia explant tissue measuring $10 \times 15 \mathrm{~mm}^{2}$

\begin{tabular}{lccccc}
\hline \hline \multirow{2}{*}{$\begin{array}{l}\text { Size of } \\
\text { explant }\end{array}$} & $76 / 11 / 26$ & $75136 / 13$ & $75 / 18 / 9$ & $75 / 19 / 178$ & $74 / 4 / 3$ \\
\cline { 2 - 6 } $1 \times(10 \times 15 \mathrm{~mm})$ & $13.5 \mathrm{a}$ & $9.0 \mathrm{a}$ & $10.7 \mathrm{a}$ & $2.1 \mathrm{a}$ & $5.0 \mathrm{~b}$ \\
$2 \times(5 \times 15 \mathrm{~mm})$ & $28.0 \mathrm{~b}$ & $16.9 \mathrm{~b}$ & $21.7 \mathrm{~b}$ & $7.6 \mathrm{~b}$ & $8.0 \mathrm{c}$ \\
$3 \times(3.3 \times 15 \mathrm{~mm})$ & $44.4 \mathrm{c}$ & $30.6 \mathrm{c}$ & $28.9 \mathrm{c}$ & $9.0 \mathrm{~b}$ & $2.6 \mathrm{a}$ \\
\hline
\end{tabular}

'The numbers given are calculations based on a regression model. Values followed by the same letter do not differ significantly $(P<0.05)$. and the significance of differences between values was determined separately for each hybrid.

Explant size. For all hybrids, a reduction in the length of explants from 10 to $5 \mathrm{~mm}$ resulted in a statistically significant increase in the number of buds (Table 4). A further reduction in the length of explants to $3.3 \mathrm{~mm}$ led to a further significant increase in bud formation by three hybrids: $76 / 11 / 26,75 / 36 / 13$, and $75 / 18 / 9$, while the increase was not significant for $75 / 19 / 178$. In the case of $74 / 43 / 3$, the reduction in length. to $3.3 \mathrm{~mm}$ resulted in a decrease in the number of buds produced. Explants with a length of 10 or 5 $\mathrm{mm}$ generally formed buds on the proximal end. Short explants $(3.3 \mathrm{~mm})$ tended to form buds on the proximal and the distal ends.

Our results indicated that the physiological stage of the donor plant played an important role in determining the regeneration potential of cultured Lachenalia leaf tissue. Results also suggested that the optimum stage was different for each cultivar and that tissue from different positions on the leaf responded differently. The effect of the genotype could be demonstrated clearly by the differences between 'Rosabeth' and 'Roinge', two hybrids with the same parents. They differed not only in the optimal stage of the donor plants, but also in the response of tissue from the center of the leaf. Other workers also found that the physiological age of the donor plant can be a critical factor in determining shoot regeneration (Niimi and Onozawa, 1979; Wright and Alderson, 1980; Hanh et al., 1981). That tissue of 'Rosabeth' and 'Romelia' formed a relatively high number of buds after flowering was unexpected, as regeneration is often obtained from young or actively growing tissue (Pierik and Ippel,
1977; Nel, 1983). The results with Lachenalia showed that the effect of the genotype on bud formation should be taken into account when a protocol for rapid propagation of different cultivars is being developed.

The observation that Lachenalia buds formed from adaxial epidermal cells regardless of the orientation of the leaf explant is in accordance with the observations of other researchers (Leshem et al., 1982; Johnson and Pittman, 1986). These authors found, however, that bud production decreases when the bud-forming cells are in contact with the medium, which contradicts our results. The ability of Lachenalia leaf tissue to form buds regardless of explant orientation could be due to the regeneration potential of Lachenalia leaf tissue. However, growth of Lachenalia buds appeared to be negatively affected when they were submerged in medium, as hard callus-like tissue was formed.

The stimulating effect of wounding on the initiation of adventitious buds has been indicated by others (Bajaj, 1972; Rest and Paterson, 1976; Van Aartrjik and BlomBarnhoorn, 1983, 1985). However, Lachenalia hybrids did not respond to wounding in the same manner; wounding of certain hybrids did not stimulate bud initiation. Growth, as a result of the wound cuts, was invariably on the distal side of the cuts, either as adventitious buds on the adaxial side or callus on the abaxial side. This pattern may indicate that not only was wounding involved, but, possibly, also the basipetal transport of auxin (Van Aartrijk and Blom-Barnhoorn, 1985) from the distal to the proximal ends of the tissue between cuts. That both adaxial and abaxial wounding promoted bud formation may indicate that auxin was transported through both the abaxial and adaxial parenchyma.

The regeneration potential of tissue can be positively correlated with the size of the explant (Pierik and Post, 1975; Dunwell, 1981; Johnson and Pittman, 1986). Our results are in agreement with those of Wright and Alderson (1980) and Van Aartrijk and BlomBarnhoorn (1983) and indicate that a reduction in explant size leads to an increase in the total number of shoots obtained from a given amount of explant tissue. This result possibly may be explained by the polarity of regeneration on explants. As a result of polar regeneration, it is important to dissect the tissue in such a way that the transverse ends are the long ends of the explant. The hybrids that showed a progressive increase in bud production with a reduction in explant length had a relatively high regeneration potential in comparison with the two lines that did not show an increase in bud production when explant length was reduced to $3.3 \mathrm{~mm}$.

Results obtained in this study with Lachrenalia leaves thus demonstrate the importance of the condition of the donor plant and the explant itself on the initiation of buds. According to Dunwell (1981) and Pierik and Ippel (1977), those factors could be the most important of all the factors that affect regeneration. The practical implication for rapid propagation of Lachenalia is that 1) leaf explants should be placed horizontally, with the abaxial side on the medium, 2) smaller explants produce more buds, and 3) the optimal stage of the donor plant for bud production may differ for each cultivar.

\section{Literature Cited}

Bajaj, Y.P.S. 1972. Effect of some growth regulators on bud formation by excised leaves of Torenia fournieri. Z. Pflanzenphysiol. 66:284287.

Dunwell, J.M. 1981. In vitro regeneration from excised leaf discs of three Brassica species. J. Expt. Bet. 32:789-799.

Hanh., T.T., H. Lie-Schricke, and K. Tran Thanh Van. 1981. Direct in vivo bud formation from fragments and thin cell layers of different organs of winged bean (Psophocarpus tetragonolobus L. DC). Z. Pflanzenphysiol. 102: $127-$ 139.

Johnson, B.B. and R.N. Pittman. 1986. Factors affecting in vitro differentiation of explants from mature leaves of Arachis villosulicarpa Hoehne. In Vivo Cell Dev. Biol. 22:713-715.

Leshem, B., H. Lilien-Kipnis, and B. Steinitz. 1982. The effect of light and of explant orientation on the regeneration and subsequent growth of bulblets on Lillium longiflorum Thunb. bulbscale section cultured in vitro. Sci. Hort. 17: 129136.

Murashige, T. and F. Skoog. 1962. A revised medium for rapid growth and bioassays with tobacco tissue cultures. Physiol. Plant. 15:473497.

Nel, D.D. 1983. Rapid propagation of Lachenalia hybrids in vitro. S. Afr. J. Bet. 2:245-246.

Niimi, Y. and T. Onozawa: 1979. In vitro bulblet formation from leaf segments of lilies, especially Lilium rubellum Baker. Sci. Hort. 11:379389. 
Pierik, R.L.M. and B.J. Ippel. 1977. Plantlet formation from excised bulb scale segments of Nerine. Acta Hort. 78:197-202.

Pierik, R.L.M. and A.J.M. Post. 1975. Rapid vegetative propagation of Hyacinths orientalism L. in vitro. Sci. Hort. 3:293-297.

Rost, T.L. and K. Paterson. 1976. The developmental anatomy of adventive plantlets from leaves and leaf segments of Crassula argentea
(Crassulaceae). Bet. Gaz. 137:203-210.

Van Aartrijk, J. and G.J. Blom-Barnhoorn. 1983. Adventitious bud formation from bulb-scale explants of Lillium speciosum Thunb. in vitro. Effect of wounding, TIBA, and temperature. $\mathrm{Z}$. Pflanzenphysiol. 110:355-363.

Van Aartrijk, J. and G.J. Blom-Barnhoorn. 1985. Adventitious bud formation from bulb-scale explants of Lilium speciosum Thunb. in vitro. Ef- fects of amino-ethoxyvinyl-glycine, 1aminocyclopropane-1-carboxylic acid, and ethylene. J. Plant Physiol. 117:401-410.

Van Rensburg, J.G.J. and J. Van Staden. 1988. Initiation of adventitious buds from Lachenalia leaf tissue in vitro. Proc. Annu. Congr. S. Afr. Assn. Bet. p. 83. (Abstr.)

Wright, N.A. and P.G. Alderson. 1980. The growth of tulip tissues in vitro. Acta Hort. 109:263270 .

\section{Micropropagation of the Aquatic Plant Cryptocoryne lucens}

\author{
Michael E. Kane, Edward F. Gilman, Matthew A. Jenks, and \\ Thomas J. Sheehan \\ Department of Environmental Horticulture, IFAS, University of Florida, \\ Gainesville, FL 32611
}

Additional index words. aquarium plant, in vitro culture, growth regulators, Araceae

Abstract. Procedures for in vitro establishment, rapid shoot proliferation, and ex vitro plantlet acclimatization of Cryptocoryne lucens de Witt were determined. Shoot cultures were established from surface-sterilized shoot tips cultured on Linsmaier and Skoog salts and vitamins medium (LS) solidified with $0.8 \%(\mathrm{w} / \mathrm{v})$ agar and supplemented with $2.0 \mu \mathrm{M}$ BA and $0.5 \mu \mathrm{M}$ NAA. The effect of BA (0 to $20 \mu \mathrm{M})$ and $0.5 \mu \mathrm{M}$ NAA on shoot multiplication from single-node and clustered triple-node shoot explants was determined after 35 days. The most efficient shoot proliferation ( 7.7 shoots/explant) occurred from single-node shoot explants cultured on LS + 20 $\mu \mathrm{M}$ BA and $0.5 \mu \mathrm{M}$ NAA. Maximum plantlet establishment was achieved by direct sticking of triple-node (cluster) microcuttings in either soilless planting medium or polyurethane foam cubes. Production of highly branched salable plants from microcuttings was possible within 18 weeks. Chemical names used: N-(phenylmethyl) -1H-purin-6-amine (BA); 1-naphthaleneacetic acid (NAA).

The genus Cryptocoryne (Araceae) contains some of the most commercially important ornamental aquatic species used in the aquarium plant trade (Rataj and Horeman, 1977). Most cryptocorynes are native to southeast Asia and Indonesia and grow either submersed or emersed. Seed production is rare and vegetative propagation by rhizome division is extremely slow (Windelov, 1987). Therefore, most Cryptocoryne spp. sold in the United States are collected from natural populations, imported, subdivided into unbranched plantlets, and maintained in holding tanks before sale. Unreliable supply from the export countries combined with frequent loss of plants to a poorly characterized leaf decomposition disease, commonly termed "cryptocoryne melt down" (D. Bryan, personal communication), have decreased the availability of quality plants. In vitro production of Cryptocoryne spp. could alleviate both problems of supply and quality.

Several studies have demonstrated that certain aquatic plants are amenable to in vi-

Received for publication 16 May 1989. Florida Agr. Expt. Sta. J. Ser. no. 9950. Funded in part through the IFAS Center for Natural Resources. The cost of publishing this paper was defrayed in part by the payment of page charges. Under postal regulations, this paper therefore must be hereby marked advertisement solely to indicate this fact. tro propagation either by proliferation from pre-existing buds (Harder. 1968: Kane et al.. 1988b; Uma and Mohan Ram, 1972) or through adventitious shoot formation (Kane et al., 1988a; Kane and Albert, 1989; Rao

Table 1. Effect of BA on mean shoot multiplication of Cryptocoryne lucens from single- and triplenode explants cultured for 35 days.

\begin{tabular}{|c|c|c|c|c|c|c|}
\hline \multirow[b]{2}{*}{ Explant } & \multicolumn{6}{|c|}{$\mathrm{BA}(\mu \mathrm{M})$} \\
\hline & $\theta$ & 0.5 & 2.5 & 5 & 10 & 20 \\
\hline $\begin{array}{l}\text { Single-node } \\
\text { Triple-node }\end{array}$ & $\begin{array}{c}4.0 \\
8.8(2.9)\end{array}$ & $\begin{array}{c}4.5 \\
8.0(2.7)\end{array}$ & $\begin{array}{c}\text { Shoots p } \\
5.4 \\
10.3(3.4)\end{array}$ & $\begin{array}{c}\text { tuced (no.) } \\
5.4 \\
12.8(4.3)\end{array}$ & $\begin{array}{c}5.6 \\
11.5(3.0)\end{array}$ & $\begin{array}{r}7.7 \\
13.4(4.5)\end{array}$ \\
\hline Source of variation & & $\mathrm{df}$ & MS & $\mathrm{F}$ & Prob $>F$ & \\
\hline $\begin{array}{l}\text { Explant }(\mathrm{E}) \\
\text { Concentration }(\mathrm{C}) \\
\text { ExC } \\
\text { Error }\end{array}$ & & $\begin{array}{r}1 \\
5 \\
5 \\
283\end{array}$ & $\begin{array}{c}2111.84 \\
134.53 \\
20.67 \\
6.9\end{array}$ & $\begin{array}{r}305.50 \\
19.46 \\
2.99\end{array}$ & $\begin{array}{r}<0.001 \\
<0.001 \\
0.012\end{array}$ & \\
\hline
\end{tabular}

${ }^{2}$ Values in parenthesis represent mean number of shoots produced per explant node.

Table 2. Post-transplant survival and branching of single- and triple-node microcuttings 6fryptocoryne lucens after 18 weeks.

\begin{tabular}{|c|c|c|c|c|c|}
\hline \multirow{2}{*}{$\begin{array}{l}\text { Planting } \\
\text { medium }\end{array}$} & \multirow[b]{2}{*}{$\mathrm{N}$} & \multicolumn{2}{|c|}{ Microcutting survival (\%) } & \multicolumn{2}{|c|}{ No. branches/microcutting type } \\
\hline & & Single-node & Triple-node & Single-node & Triple-node \\
\hline $\begin{array}{l}\text { Polyurethane foam } \\
\text { cubes }\end{array}$ & 144 & 69.9 & 99.3 & 3.8 & 11.9 \\
\hline \multicolumn{6}{|l|}{ Vergro } \\
\hline 4-cell pack & 48 & 45.8 & 91.7 & 5.3 & 11.9 \\
\hline 12-cell pack & 48 & 97.9 & 100 & 7.2 & 11.0 \\
\hline Tukey's HSD (0.05) & & & & \multicolumn{2}{|c|}{3.1} \\
\hline
\end{tabular}

